\title{
Development of a High-Throughput Diagnosis Method for Detecting the ALDH2 Gene Using Fingernail DNA
}

\author{
Emi Nagayoshi, Yoko Mizuta and Yukio Takii
}

\author{
Department of Bioscience and Biotechnology, Faculty of Bioenvironmental Science, Kyoto Gakuen \\ University, 1-1 Nanjyo-Otani, Sogabe-cho, Kameoka, Kyoto 621-8555, Japan
}

\begin{abstract}
A clinical method for effective genetic screening of the aldehyde dehydrogenase 2 (ALDH2) gene was developed, using the fingernail as a source of DNA material. A highly effective protease that could solubilize fingernail keratin and inactivate any DNase co-existing in the tissue was obtained by cloning and sequencing the gene for alkaline protease from Bacillus alcalophilus, followed by expression of the gene in Bacillus subtilis. The amino acid sequence of MIB029 protease contained common regions found in four other subtilisin-like proteases. In the fingernails of 113 female university students (average age $20.8 \pm 0.7$ years; body mass index, $20.4 \pm 1.6$ ), ALDH2 frequency was 0.66 for the typical Glu homozygote, 0.32 for the heterozygote (Glu487Lys), and 0.020 for the atypical Lys homozygote. Through a questionnaire, it was found that the subjects had not previously received information regarding the relationship between their genetic background and consumption of alcoholic beverages. We found that the genetic single nucleotide polymorphism (SNP) background to alcoholism can be easily detected by collecting fingernails, which is convenient for subjects or patients.
\end{abstract}

Keywords: ALDH2 gene detection, genetic diagnosis, keratinolytic, Bacillus, alkaline protease.

\section{INTRODUCTION}

The symptoms of lifestyle-related disease are generally caused by interactions between hereditary predisposition and environmental factors [1, 2]. Although hereditary predisposition toward diseases such as alcoholism cannot be altered, individuals should be educated about their hereditary predisposition [3]. Aldehyde dehydrogenase 2 (ALDH2; EC 1.2.1.10) is a key enzyme involved in alcohol metabolism. A single-nucleotide polymorphism (SNP), Glu487Lys in the ALDH2 gene (rs671: $135 \mathrm{bp}$ ), is commonly found in Orientals, and is responsible for alcohol intolerance [4-7]. The individual acceptable alcohol consumption level is affected by the individual capacity for metabolizing acetaldehyde, a harmful product of alcohol metabolism [4, 5, 7]. In ALDH2 deficiency, one codon on exon 12 of the ALDH2 gene (the 487th codon in the whole gene) is GAA in individuals with the typical allele associated with high tolerance to alcohol $(A L D H 2 * 1)$ and AAA in those with the atypical allele associated with less tolerance to alcohol $(A L D H 2 * 2)$, with the corresponding amino acid substitution of lysine for glutamate. The single amino acid substitution by this single base substitution results in a dramatic loss of ALDH activity. Individuals heterozygous for the typical and atypical alleles $(A L D H 2 * 1 / A L D H 2 * 2)$ possess inherently reduced ALDH2 activity $[4,5]$.

*Address correspondence to this author at the Department of Bioscience and Biotechnology, Faculty of Bioenvironmental Science, Kyoto Gakuen University, 1-1 Nanjyo-Otani, Sogabe-cho, Kameoka, Kyoto 621-8555, Japan; Tel: +81 77129 3494; Fax: +81 77129 3426; E-mail: ztakii@kyotogakuen.ac.jp
An ethanol patch test [8] and questionnaire method are currently available as screening methods for alcohol sensitivity in minors. Although the ethanol patch test provides rapid results, it has disadvantages, including skin irritation potential and variability in assessment results depending on the subjects' physical conditions. In contrast, although the questionnaire method is performed using the Tokyo University ALDH2 Phenotype Screening Test (TAST), which is developed by modifying the international standard method the Aldolescent Alcohol Involvement Scale [9] for use in Japanese people [10], it is thought that it cannot be applied to minors or nondrinkers because it contains many questions that cannot be answered by individuals who have never drunk alcohol.

Fingernail sampling can be easily carried out at any time, in any location, and from any person, and handling of samples is simple. Since samples can be kept at room temperature, sampling can be done by family members and delivered through the postal service.

However, fingernails are composed of hard and insoluble keratin, making it difficult to extract DNA from the nail tissues. Moreover, the tissues contain many DNases that decrease the DNA content during preparation [11].

In the present study, we used alkaline serine protease from Bacillus alcalophilus subsp. halodurans MIB029 because it is highly active at $\mathrm{pH} 11.0$ and $70^{\circ} \mathrm{C}$ [12]. Additionally, the enzyme functions efficiently in the presence of EDTA, which effectively eliminates 
contaminating DNases in the sample. To determine the current state of alcoholic beverage consumption in minors, fingernail sampling and ethanol patch test were conducted, and any subjects with a history of alcohol consumption were also asked about their intake and frequency of alcoholic beverage consumption to investigate potential associations with ALDH2 hereditary predisposition.

Our goal was to develop a gene expression system for obtaining large amounts of the alkaline protease. We propose a simple diagnostic method using nail clippings that can be used to determine various genotypes associated with lifestyle-related diseases.

\section{MATERIALS AND METHODS}

\subsection{Bacterial Strains and Cell Culture}

Bacillus alcalophilus subsp. halodurans MIB029 (formerly designated as $\mathrm{KP} 1239$ ) was cultured in medium I, which contained $0.3 \% \mathrm{KH}_{2} \mathrm{PO}_{4}, 0.5 \%$ yeast extract, $0.5 \%$ peptone, and $0.5 \% \mathrm{NaHCO}_{3}(\mathrm{pH} 8.3$ ), as described previously [13]. Bacillus subtilis DB104 cells bearing each expression plasmid were cultivated at $30^{\circ} \mathrm{C}$ on LB medium plates containing kanamycin (10 $\mu \mathrm{g} / \mathrm{mL})$.

\subsection{Primers and Sequence Analysis}

Genomic DNA for strain MIB029 was prepared using the method of Saito and Miura [13]. To amplify the alkaline protease gene, two primers were synthesized: forward primer, 5'-aggacatatgGCGCAA TCAGTGCCATGGGGAATTAG-3' and reverse primer, 5'-aggaaagcTTAGCGTGTTGCCGCTTCTGCATTGAC AAGGCGACACTTGAGCA AGCTGTT-3'.

PCR amplification was performed using a PCR kit (TaKaRa PCR Thermal Cycler TP600, Shiga, Japan) using $86.8 \mathrm{ng}$ of MIB029 genomic DNA as template, 10 $\mu \mathrm{L}$ of $5 \times$ reaction buffer $\left(\mathrm{Mg}^{2+}\right.$ plus), $4 \mu \mathrm{L}$ each of 2.5 $\mathrm{mM}$ dNTP, $10 \mathrm{pmol}$ of each primer, and $1.25 \mathrm{U}$ of PrimeSTAR $\circledast$ HS DNA polymerase in a total volume of $50 \mu \mathrm{L}$. The mixture was subjected to 30 cycles of amplification: $98^{\circ} \mathrm{C}$ for $10 \mathrm{sec}, 55^{\circ} \mathrm{C}$ for $5 \mathrm{sec}$, and $72^{\circ} \mathrm{C}$ for $45 \mathrm{sec}$, then $72^{\circ} \mathrm{C}$ for 5 min ( 1 cycle). The PCR product was purified using the TaKaRa Agarose Gel DNA Purification Kit Ver.2.0, and subsequently digested with both $15 \mathrm{U}$ of Pstl and Hindlll restriction enzymes.

The pNCM02 Vector (100 ng: TaKaRa) was digested at $37^{\circ} \mathrm{C}$ for $4 \mathrm{~h}$ with $15 \mathrm{U}$ of Pstl and HindllI and purified using the Purification Kit Ver.2.0 (TaKaRa). Insert DNA (100 ng) was ligated to vector DNA (50 ng) at $16^{\circ} \mathrm{C}$ for $4 \mathrm{~h}$. Next, $10 \mu \mathrm{L}$ of the ligated mixture transformed into $100 \mu \mathrm{L}$ Escherichia coli competent cells JM109 (TaKaRa Dalian Code No. D9052). A PCR fragment of the MIB029 gene was transferred into the host Bacillus subtilis DB104 and selected for on LB medium containing $10 \mu \mathrm{g} / \mathrm{mL}$ kanamycin. Expression was conducted in the same medium.

\subsection{Stage 1 - Testing Human Nail Clippings as Useful Genetic Tools}

Nail tissues collected from 20 volunteers were cut into pieces $(1.0 \times 2.0 \mathrm{~mm})$, rinsed twice with $100 \mathrm{~mL}$ of deionized water, and washed with $30 \mathrm{~mL}$ of ethanol. Samples were dried and stored at room temperature until use. The specimen was found to be stable during storage for at least 6 months.

\subsection{Enzyme Assays and Protein Measurement}

A mixture $(1.0 \mathrm{~mL})$ of $100 \mathrm{mM}$ glycine- $\mathrm{NaOH}$ buffer (pH 11), $5 \mathrm{mg}$ nail clippings, and $100 \mathrm{mM}$ EDTA was incubated at $70^{\circ} \mathrm{C}$ for $10-30 \mathrm{~min}$, mixed with $1 \mathrm{~mL}$ of trichloroacetic acid, and boiled for $3 \mathrm{~min}$ prior to centrifugation at $7500 \mathrm{xg}$ for $2 \mathrm{~min}$ at $25^{\circ} \mathrm{C}$ [12]. The $A_{275}$ (1-cm light path) of the supernatant was measured and converted to an equivalent amount of tyrosine. One unit $(U)$ of enzyme activity was defined as the amount of enzyme releasing $1 \mu \mathrm{mol}$ of tyrosine equivalent/min. Protein concentration was assessed using the Bradford method with bovine serum albumin as the standard [12].

Table 1: Physical Characterisitics of Participants

\begin{tabular}{|l|c|}
\hline Numer of subjects & $\mathbf{1 1 3}$ \\
\hline \hline Sex & females \\
\hline Age, years & $20.8 \pm 0.7$ \\
\hline Height $(\mathrm{cm})$ & $160.5 \pm 6.7$ \\
\hline Body weight $(\mathrm{kg})$ & $53.3 \pm 7.6$ \\
\hline Body mass index, $\mathrm{kg} / \mathrm{m}^{2}$ & $20.4 \pm 1.6$ \\
\hline Body fat percentage $(\%)$ & $28.8 \pm 5.6$ \\
\hline
\end{tabular}

Values are mean \pm standard deviation.

\subsection{Stage 2 Diagnosis Studies Using Nail Clippings as Sources for the ALDH2 Gene}

All of the following procedures were conducted with the approval of the research ethics committee of this 
University. Informed consent was obtained from each of the 113 healthy female students (average age $20.8 \pm$ 0.7 years; body mass index, $20.4 \pm 1.6)$ ) who stated that they had never suffered from alcoholism or alcohol abuse (Table 1).

\subsubsection{DNA Extraction from Fingernails}

Each specimen prepared from nail clippings (5.0 $\mathrm{mg}$ ) from the 113 participants was transferred into a 1.5-mL microcentrifuge tube containing $200 \mu \mathrm{L}$ of 100 $\mathrm{mM}$ glycine- $\mathrm{NaOH}$ buffer $(\mathrm{pH} 11)$ and $100 \mathrm{mM}$ EDTA and incubated for $30 \mathrm{~min}$ at $70^{\circ} \mathrm{C}$. The DNA was dissolved in $10 \mu$ l of TE buffer ( $\mathrm{pH} 8.0$ ).

\subsubsection{Ethanol Patch Test}

A piece of gauze soaked with $70 \%$ ethanol was applied directly to the participants' medial upper arm and removed after 7 minutes, and the color of the skin area in contact with the gauze was observed within 5 seconds. At 10 minutes after the removal of the gauze, the skin color was again observed [8]. If the skin was red immediately after the removal of the gauze, the participant was considered as having no ALDH2 activity, indicating alcohol intolerance. If the skin was not red immediately after the removal of the gauze but was red at 10 minutes, the participant was considered as having reduced ALDH2 activity, indicating low alcohol tolerance. If the skin color remained unchanged, the participant was considered as having normal ALDH2 activity, indicating high alcohol tolerance $[6,8]$.

\subsubsection{Questionares to the Subjects About Alcohol Drinking}

In accordance to the ethanol patch test, four questions were given to the participants who has drunken, as shown in Table 2.

\subsubsection{PCR Amplification of the ALDH2 Gene}

The allele-specific ALDH2 gene was amplified using forward primer $(F)$ and reverse primer $\mathrm{R} 1$ or reverse primer R2 [5]. R1 and R2 represent Glu at 487 and Lys at 487 , respectively [4-7].

\section{F: 5'-CAATTACAGGGTCAACTGCT-3'}

\section{R1: 5'-CCACACACTCACAGTTTTCTCTTC-3'}

\section{R2 : 5'-CCACACTCACAGTTTTCTCTTT-3'}

A total of $50 \mu \mathrm{L}$ PCR solution containing $1 \times$ PCR buffer, template DNA, $0.5 \mathrm{mM}$ MgSO 4, $0.2 \mathrm{mM}$ dNTP, $0.4 \mathrm{mM}$ forward primer, $0.4 \mathrm{mM}$ reverse primer $\mathrm{R} 1$ or $\mathrm{R} 2$, and 1.25 KOD plus enzyme was pre-heated at $98^{\circ} \mathrm{C}$ for $1 \mathrm{~min}$, and then subjected to 35 cycles of amplification by PCR as follows: $98^{\circ} \mathrm{C}$ for $20 \mathrm{sec}, 60^{\circ} \mathrm{C}$ for $20 \mathrm{sec}$, and $72^{\circ} \mathrm{C}$ for $45 \mathrm{sec}$. After the cycle, final extension was carried out for $5 \mathrm{~min}$ at $72^{\circ} \mathrm{C}$ and the sample was stored at $4^{\circ} \mathrm{C}$.

\subsubsection{Agarose Gel Electrophoresis}

A 5- $\mu \mathrm{L}$ sample of the PCR product was analyzed on a $3 \%$ agarose $21 \mathrm{gel}$ [8]. Electrophoresis was carried out at $50 \mathrm{~V}$ for $30 \mathrm{~min}$. DNA was visualized by staining with ethidium bromide [11].

\section{RESULTS}

\subsection{Gene Structure of MIB029 Protease}

The gene encoding serine alkaline protease from $B$. alcalophilus subsp. halodurans MIB 029 is depicted in Figure 1. The open reading frame was 1140 bases. The deduced amino acid sequence was a pre-propeptide of 111 residues followed by the mature protease consisting of 269 residues. The protein showed a molecular weight of $29,000 \mathrm{~d}$ and a sedimentation coefficient in water at $20^{\circ} \mathrm{C}$ of $3.3 \mathrm{~S}$, as

Table 2: Questions of Habitual Drinking

\begin{tabular}{|l|l|}
\hline Q1 & How often do you have a drink containing alcohol? \\
\hline Q2 & (0) Never (1) Monthly or less (2) Two to four times a month (3)Two to three times a week (4)Four times a week \\
\hline & How many drinks containing alcohol do you have on a typical day when you are drinking? \\
\hline Q3 & (0) 1 or 2 (1) 3 or4 (2) 5 or 6 (3) 7 or 8 (4) 10 or more \\
\hline & How often do you have six or more drinks on one occasion? \\
\hline Q4 & (0) Never (1) Less than monthly (2) Monthly (3) Weekly (4) Daily or almost daily \\
\hline & How often during the last year have found that you were not able to stop drinking once you have started? \\
\hline
\end{tabular}

In determining the response categories it has been assumed that one drink contains about $6 \mathrm{~g}$ alcohol.

Sum of individual item scores were recorded to determin types of drinking. 
TTCCCAATAGGCAAATCTTTCTAACTTTGATACGTTTAAACTACCAGCTTGGACAAGTTGTATAAAAATGAGGAGGGAACCCGA 20

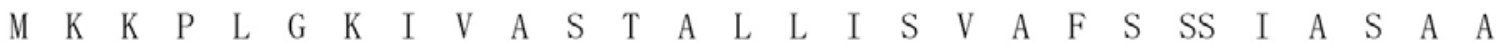
ATGAAGAAACCGTTGGGGAAAATTGTCGCAAGCACCGCACTACTCATTTCTGTTGCTTTTAGTTCATCGATCGCATCGGCTGCT

40

$\begin{array}{lllllllllllllllllllllllllll}\text { EE } & A & K & E & K & Y & L & I & G & F & N & E & Q & E & A & V & S & E & F & V & E & Q & V & E & A & N & D\end{array}$ GAAGAAGCAAAAGAAAAATATTTAATTGGCTTTAATGAGCAGGAAGCTGTTAGTGAGTTTGTAGAACAAGTAGAGGCAAATGAC 100 120 140 160

60

$\begin{array}{llllllllllllllllllllllllll}\underline{D} & V & A & I & L & S & E & E E E & V & E & I & E & L & L & H & E & F & E & T & I & P & V & L & S & V & E\end{array}$ GACGTCGCCATTCTCTCTGAGGAAGAGGAAGTCGAAATTGAATTGCTTCATGAATTTGAAACGATTCCTGTTTTATCCGTTGAG 180 200 220 240

100

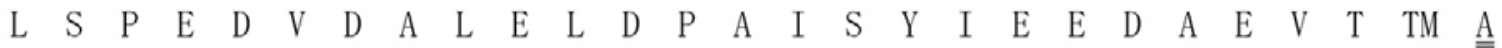
TTAAGCCCAGAAGATGTGGACGCGCTTGAACTCGATCCAGCGATTTCTTATATTGAAGAGGATGCAGAAGTAACGACAATGGCG 260 280 300 320

120

$\begin{array}{lllllllllllllllllllllllllll}Q & \mathrm{~S} & \mathrm{~V} & \mathrm{P} & \mathrm{W} & \mathrm{G} & \mathrm{IS} & \mathrm{R} & \mathrm{V} & \mathrm{Q} & \mathrm{A} & \mathrm{P} & \mathrm{A} & \mathrm{A} & \mathrm{H} & \mathrm{N} & \mathrm{R} & \mathrm{G} & \mathrm{L} & \mathrm{T} & \mathrm{G} & \mathrm{S} & \mathrm{G} & \mathrm{V} & \mathrm{K} & \mathrm{V} & \mathrm{A}\end{array}$ CAATCAGTGCCATGGGGAATTAGCCGTGTGCAAGCCCCAGCTGCCCATAACCGTGGATTGACAGGTTCTGGTGTAAAAGTTGCT 340 360 380 400

$\begin{array}{llllllllllllllllllllllllllll}V & \mathrm{~L} & \mathrm{D} & \mathrm{T} & \mathrm{G} & \mathrm{I} & \mathrm{S} & \mathrm{T} & \mathrm{H} & \mathrm{P} & \mathrm{D} & \mathrm{L} & \mathrm{N} & \mathrm{I} & \mathrm{R} & \mathrm{G} & \mathrm{G} & \mathrm{A} & \mathrm{S} & \mathrm{F} & \mathrm{V} & \mathrm{P} & \mathrm{G} & \mathrm{E} & \mathrm{P} & \mathrm{S} & \mathrm{T} & \mathrm{Q}\end{array}$ GTCCTCGATACAGGTATTTCCACTCATCCAGACTTAAATATTCGTGGTGGCGCTAGCTTTGTACCAGGGGAACCATCCACTCAA 440 460 480 500 180

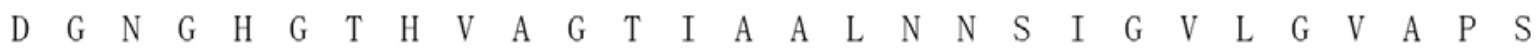
GATGGGAATGGGCATGGCACGCATGTGGCCGGGACGATTGCTGCTTTAAACAATTCGATTGGCGTTCTTGGCGTAGCGCCGAGC 520 540 560 580 200 220

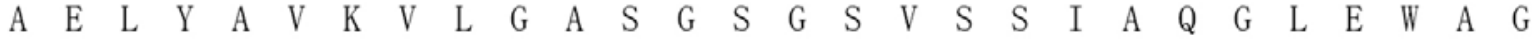
GCGGAACTATACGCTGTTAAAGTATTAGGGGCGAGCGGTTCAGGTTCGGTCAGCTCGATTGCCCAAGGATTGGAATGGGCAGGG 600 620 640 660 240

$\begin{array}{llllllllllllllllllllllllllll}N & N & G & M & H & V & A & N & \text { L } & \text { S } & \text { L } & G & \text { S } & \text { P } & \text { S } & \text { P } & \text { S } & \text { A } & \text { T } & \text { L } & \text { E } & \text { Q } & \text { A } & \text { V } & \text { N } & \text { S } & \text { A } & \text { T }\end{array}$ AACAATGGCATGCACGTTGCTAATTTGAGTTTAGGAAGCCCTTCGCCAAGTGCCACACTTGAGCAAGCTGTTAATAGCGCGACT 680 
(Figure 1). Continued.

260

$\begin{array}{lllllllllllllllllllllllllllll}\mathrm{S} & \mathrm{R} & \mathrm{G} & \mathrm{V} & \mathrm{L} & \mathrm{V} & \mathrm{V} & \mathrm{A} & \mathrm{A} & \mathrm{S} & \mathrm{G} & \mathrm{N} & \mathrm{S} & \mathrm{G} & \mathrm{A} & \mathrm{G} & \mathrm{S} & \mathrm{I} & \mathrm{S} & \mathrm{Y} & \mathrm{P} & \mathrm{A} & \mathrm{R} & \mathrm{Y} & \mathrm{A} & \mathrm{N} & \mathrm{A} & \mathrm{M}\end{array}$ TCTAGAGGGGTTCTTGTTGTAGCGGCATCTGGGAATTCAGGTGCAGGCTCAATCAGCTATCCGGCCCGTTATGCGAACGCAATG

760

780

800

820

840

300

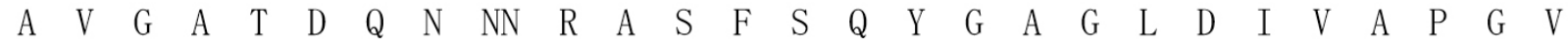
GCAGTCGGAGCGACTGACCAAAACAACAACCGCGCCAGCTTTTCACAGTATGGCGCAGGGCTTGACATTGTCGCACCAGGTGTA 860 880 900

920 320

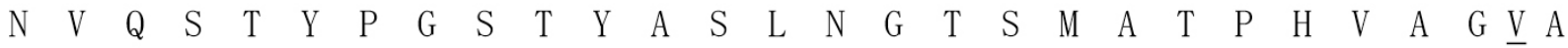
AACGTGCAGAGCACATACCCAGGTTCAACGTATGCCAGCTTAAACGGTACATCGATGGCTACTCCTCATGTTGCAGGTGTAGCA 940 960 980 1000 340 360

$\begin{array}{lllllllllllllllllllllllllllll}\text { A } & \text { L } & \text { V } & \text { K } & \text { Q } & \text { K } & \text { N } & \text { P } & \text { S } & \text { W } & \text { S } & \text { N } & \text { V } & \text { Q } & \underline{V} & R & N & H & \text { L } & \text { K } & \text { N } & \text { T } & \text { A } & \text { T } & \text { S } & \text { L } & G & \text { S }\end{array}$ GCCCTTGTTAAACAAAAGAACCCATCTTGGTCCAATGTACAAGTCCGCAATCATCTAAAGAATACGGCAACGAGCTTAGGAAGC 1020 1040 1060 1080

380

$\begin{array}{llllllllllllllllllll}\text { T } & N & \text { L } & \text { Y } & G & \text { S } & \text { G } & \text { L } & \text { V } & \text { N } & \text { A } & \text { E } & \text { A } & \text { A } & \text { T } & \text { R }\end{array}$ ACGAACTTGTATGGAAGCGGACTTGTCAATGCAGAAGCGGCAACACGCTAATCAATAATAATAGGAGCTGTCCCAAAAGGTCAT 1100

1120

1140

1160

1180

1200

1220

1240

AGATAAATGACCTTTTGGGGTGGCTTTTTTACATTTGGATAAAAAAGCACAAAAAATCGCCTCATCGTTTAAAATGAAGGTACC

Figure 1: Nucleotide sequence of the gene for MIB029 protease and deduced amino acid sequences.

Both stands were sequenced from several independent overlapping fragments. The putative SD sequence are dotted underlined. The putative transcriptional terminator is shown by the arrows $(\rightarrow \leftarrow)$. The putative transcriptional terminator is shown by the arrows at Ala334. The N-terminal sequence of 20 residues of mature enzyme deduced from DNA sequence is double underlined. The amino acids Glu32, Valine62 and Valine351 as shown in boxes are different with those of $B$. sp 221 protease (15).

demonstrated for the strain MIB029 [12]. The amino acid sequence of the mature MIB029 protease shared moderate homology with that of subtilisin-like protease (Figure 2).

MIB029 protease showed $99.8 \%$ identity with $B$. alcaophillus sp. 221 protease [14], $62.0 \%$ identity with Carlsberg [16], $99.8 \%$ with B. sp. KSM-K16 protease [16], and 61.5\% with subtilisin BPN' [17]. The regions containing the catalytic triad composed of Asp32, His62, and Ser215 of subtilisin BPN' were conserved in MIB029 protease as well as in other subtilisin-type enzymes (Figure 2). The cloned MIB029 enzyme serologically cross-reacted with the protease either from the mother strain MIB029 or B. alcaophilus sp.
221 [15], but not with subtilisin Carlsberg [16] or BPN' [17] (Figure 3).

\subsection{Properties of Cloned Protease}

Protease activity in the supernatant of $B$. subtilus DB104 bearing the alkaline protease gene reached a maximum level after $134 \mathrm{~h}$ of culture, producing 1.21 $\mathrm{U} / \mathrm{mL}$ of protein $(82.2 \mathrm{U} / \mathrm{mg})$. The protease was most active at $70^{\circ} \mathrm{C}$ in the presence of $100 \mathrm{mM}$ EDTA, whereas melon protease and proteinase $\mathrm{K}$ showed $80 \%$ and $65 \%$ activity compared with MIB029 enzyme (Figure 4). DNA extraction efficiency at $70^{\circ} \mathrm{C}$ was estimated to be $75 \%$, which was higher than that for melon protease $(69.5 \%)$ and proteinase $\mathrm{K}(60.0 \%)$ [11]. 


\begin{tabular}{|c|c|c|}
\hline MIB029 & 1 & AQSVPWG ISRVQAPAAHNRGLTGSGVKVAVLDTGI-STHPDLNIRGGASFVPGE-PSTQDGN \\
\hline No. 221 & 1 & AQSVPWG ISRVQAPAAHNRGLTGSGVKVAVLDTGI-STHPDLNIRGGASFVPGE-PSTQDGN \\
\hline KSM-K16 & 1 & AQSVPWG ISRVQAPAAHNRGLTGSGVKVAVLDTGI-STHPDLNIRGGASFVPGE-PSTQDGN \\
\hline CarIsberg & 1 & AQTVPYGIPL IKADKVQAQGFKGANVKVAVLDTGIQASHPDLNVVGGASFVAGEAYN-TDGN \\
\hline BPN' & 1 & AQSVPYGVSQIKAPALHSQGYTGSNVKVAVIDSGIDSSHPDLKVAGGASMVPSETNPFQDNN \\
\hline
\end{tabular}

\begin{tabular}{|c|c|c|}
\hline MIB029 & 61 & GHGTHVAGT I AALNNS I GVLGVAPNAELYAVKVLGASGSGSVSS IAQGLEWAGNNGMHVANL \\
\hline No. 221 & 61 & GHGTHVAGT I AALNNS I GVLGVAPNAELYAVKVLGASGSGSVSS I AQGLEWAGNNGMHVANL \\
\hline KSM-K16 & 61 & GHGTHVAGT I AALNNS I GVLGVAPSAELYAVKVLGASGSGSVSS I AQGLEWAGNNGMHVANL \\
\hline Carlsberg & 62 & GHGTHVAGTVAALDNTTGVLGVAPSVSLYAVKVLNSSGSGTYSG IVSGI EWATTNGMDVINM \\
\hline BPN' & 63 & SHGTHVAGTVAALNNS IGVLGVAPSVSLYAVKVLGADGSGQYSWI I NGI EWAI ANNMDVI INM \\
\hline
\end{tabular}

\begin{tabular}{|c|c|c|}
\hline MIB029 & 123 & SLGSPSPSATLEQAVNSATSRGVLVVAASGNSGAGS----ISYPARYANAMAVGATDQNNN \\
\hline No. 221 & 123 & SLGSPSPSATLEQAVNSATSRGVLVVAASGNSGAGS----ISYPARYANAMAVGATDQNNN \\
\hline KSM-K16 & 123 & SLGSPSPSATLEQAVNSATSRGVLVVAASGNSGAGS----ISYPARYANAMAVGATDQNNN \\
\hline Carlsberg & 124 & SLGGPSGSTAMKQAVDNAYARGVVVVAAAGNSGSSGNTNTIGYPAKYDSVI AVGAVDSNRA \\
\hline BPN' & 125 & SLGGPSGSTAMKQAVDNAYARGVVVVAAAGNSGSTGSSSTVDYPGKYPSVIAVGAVDSSNQ \\
\hline
\end{tabular}

\begin{tabular}{|c|c|c|}
\hline MIB029 & 180 & RASFSQYGAGLDIVAPGVNVQSTYPGSTYASLNGTSMATPHVAGVAALVKQKNPSWSNVQV \\
\hline No. 221 & 180 & RASFSQYGAGLDIVAPGVNVQSTYPGSTYASLNGTSMATPHVAGAAALVKQKNPSWSNVQI \\
\hline KSM-K16 & 180 & RASFSQYGAGLDIVAPGVNVQSTYPGSTYASLNGTSMATPHVAGVAALVKQKNPSWSNVQI \\
\hline ar Isberg & 185 & RASFSSVGPELEVMAPGAGVYSTYPTSTYATLNGTSMASPHVAGAAALILSKHPNLSASQV \\
\hline N' & 187 & $\begin{array}{l}\text { RASFSSVGAELDVMAPGVSIQSTLPGNKYGAYNGT } \\
* * * * * * * * * * * * * * * *\end{array}$ \\
\hline
\end{tabular}

$\begin{array}{llll}\text { MIB029 } & 241 & \text { RNHLKNTATSLGSTNLYGSGLVNAEAATR } & 269 \\ \text { No. } 221 & 241 & \text { RNHLKNTATSLGSTNLYGSGLVNAEAATR } & 269 \\ \text { KSM-K16 } & 241 & \text { RNHLKNTATGLGNTNLYGSGLVNAEAATR } & 269 \\ \text { Car Isberg } & 246 & \text { RNRLSSTATYLGSSFYYGKGLINVEAAAQ } & 274 \\ \text { BPN' } & 248 & \text { RSSLQNTTTKLGDSFYYGKGLINVQAAAQ } & 275 \\ & & * * * * * * \quad * * * * * * & \end{array}$

Figure 2: Multiple sequence alignment of MIB029 protease and four subtilisin-like enzymes.

Each amino acid sequence is numbered from the $\mathrm{N}$-terminal residues of the mature enzyme and is indicated by the single-letter codes. A common catalytic trial of the three amino acids, Asp32, His62 and Ser215 is enclosed in the box. Identical amino acid residues for all five proteases are marked with asterisks under the sequences. MIB029, MIB029 protease; 221 Bacillus sp.21 protease [14]; KSM- K16 protease, Bacillus sp. KSM- K16 [15]; BPN', Carlsberg, subtilisin Carlsberg [16]; BPN', subtilisin BPN' [17]. 


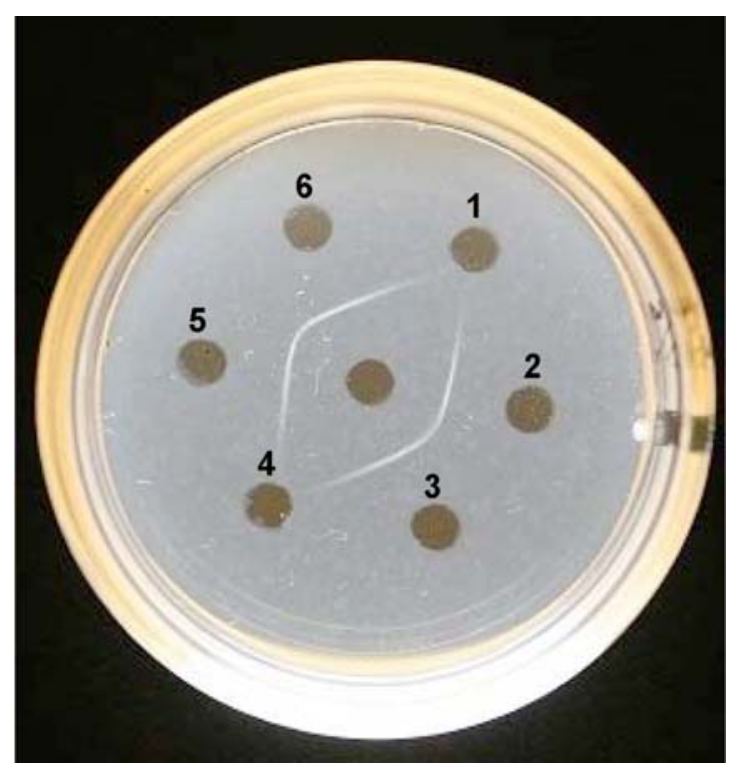

Figure 3: Double immunodiffusion.

Rabbit antiserum $(5 \mu \mathrm{l})$ prepared against $B$. alcalophilus sp. halodurans MIB029 (formerly designated as KP1239: reference 13) was added to center well (3 $\mathrm{mm}$ diameter) in plate consisting of $1.5 \%$ agarose and $25 \mathrm{mM}$ borate/ $0.1 \%$ $\mathrm{NaN}_{3} / 1 \mathrm{mM}$ PMSF. Wells 2 and 5 contained pure preparation of MIB029 protease $(1.0 \mathrm{U})$; wells 3 and 6 contained the cloned protease $(1.0 \mathrm{U})$; well 1 and 4 contained 10 -fold concentrated culture supernatant of subtilisin BPN' (1.0 U) or subtilisin Carlberg (1.3 U). Each enzyme sample used was treated at $4^{\circ} \mathrm{C}$ for $1 \mathrm{~h}$ with $1 \mathrm{mM}$ PMSF before application on the plates. Immunodiffusion on plate was carried out at at $4^{\circ} \mathrm{C}$ for $24 \mathrm{~h}$. The plate was soaked in $0.85 \% \mathrm{NaCl} / 0.1 \%$ $\mathrm{NaN}_{3}$ at $25^{\circ} \mathrm{C}$ overnight and photographed. One microliter of the antiserum completely precipitated $0.12 \mathrm{U}$ of KP1239 enzyme.
DNA purity was estimated to be 1.790 as $A_{260 / 280}$, that is identical to the value observed for Cucumis melo (data not shown).

\subsection{Application of MIB Protease for Detecting the ALDH2 Gene in Fingernail Tissues from Female Students and Alcohol Use Disorder Identification Test}

The distribution of the ALDH2 genotype in the subjects $(n=113)$ was 0.66 for the typical Glu homozygote ALDH2*1/*1, 0.32 for the heterozygote (Glu487Lys) ALDH2*1/*2, and 0.020 for the atypical Lys homozygote ALDH2*2/*2 (Figure 5). ALDH2 composed of 499 amino acid residues and its gene showed that the Glu489Lys polymorphism [4-7]. ALDH2*1/*1homozyte is highly tolerant to alcohol, the ALDH2*1/*2 (Glu 489Lys) heterozygote is less tolerant to alcohol, and the $\mathrm{ALDH}^{*} 2{ }^{*} 2$ homozygote is intolerant to alcohol.

The alcohol disorder identification test [22] was carried out for all subjects using a health and lifestyle questionnaire, if they have drunk alcohol bebarages (Table 3 ). The questionnaire was adjusted to the levels of Japanese drinking habits and lifestyles."Chance drinkers" and "past drinkers" were found to have ALDH2*1/*1 and ALDH2*1/*2, but not ALDH2*2/*2. "Non-drinkers" showed the genotype $\mathrm{ALDH} 2{ }^{*} 2{ }^{*} 2$, indicating intolerance to alcohol. Equivocal evidence of associations with genotypes was found, although this

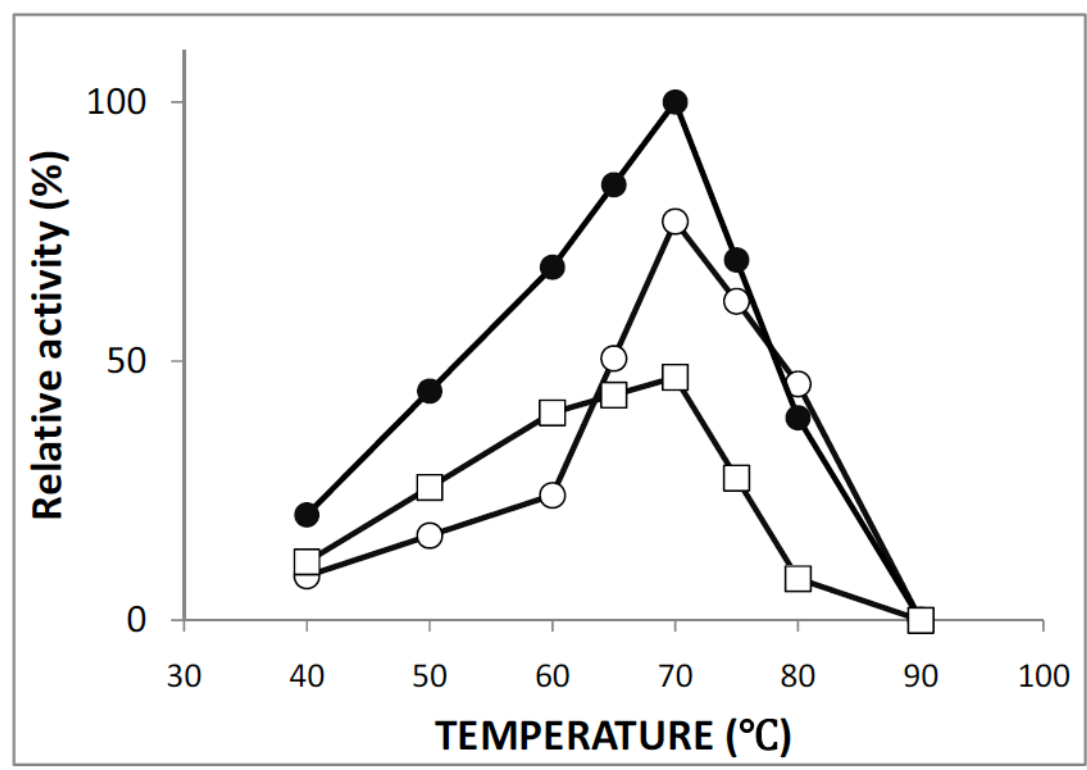

Figure 4: Effect of temperature on the activity of MIB029 protease.

The activity of MIB029 protease $(\bullet)$ was measured as in Enzyme assay, Materilas and methods, except that the incubation temperature was changed, as shown in the figure. The activity was compared with melon protease $(\circ)$ and proteinase $\mathrm{K}(\square)$, respectively. The activity observed at $4^{\circ} \mathrm{C}$ was defied as $100 \%$.

Data are presented as an average of 3 data points, with each value within $\pm 5 \%$ of the average value. 


\section{$\begin{array}{lllllll}1 & 2 & 3 & 4 & 5 & 6 & 7\end{array}$}

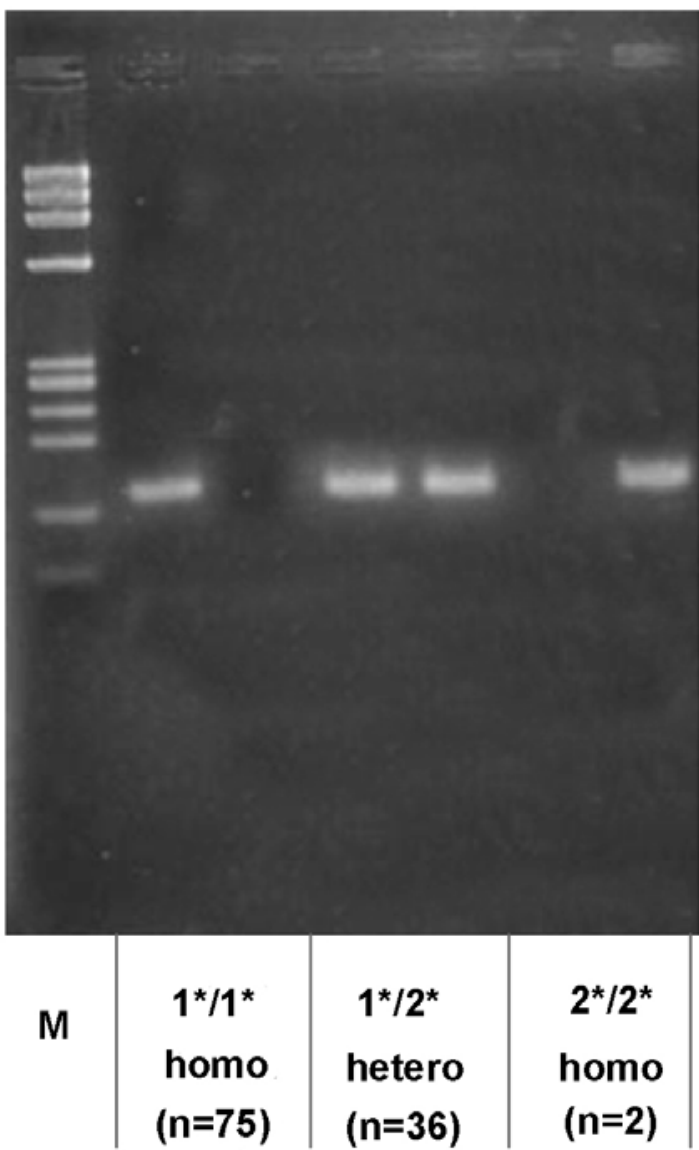

Figure 5: Electrophoresis pattern of the PCR product of a 135 bp DNA fragment containing ALDH2 exon 12 from human nail clippings.

Lane 1, DNA fragment markers: Haelll digest of $\varphi$ X174 DNA, consisting of $1353,1078,872,603,310,281,271,234,194$, 118 and 72 base pairs; lanes 2 and 3, 135 bp DNA fragments for homozyte $1^{*}$ and $1^{*}$, lanes 4 and 5, 135 bp DNA fragments for heterozyte $1^{*}$ and $2^{*}$; lane 6 and 7, $135 \mathrm{bp}$ DNA fragments for homozyte, $2^{*}$ and $2^{*}$. Lane 2, using FR1; Lane 3, using RF2; lane 4, using FR1; lane 5, using FR2; lane 6, using FR1 and lane 7, using FR2.

result was based only on responses from the participants with a history of alcohol consumption (Table 3). Participants with the typical homozygous genotype $\left({ }^{*} 1 /{ }^{*} 1\right)$, who were highly tolerant to alcohol, demonstrated essentially unchanged skin color after the ethanol patch test, indicating a clear positive correlation with the genotype (93\%; Table 4). A positive reaction with skin flushing was observed in $43(93 \%)$ of 46 participants having the intermediate heterozygous genotype with weak enzymatic activity $\left({ }^{*} 1 /{ }^{*} 2\right)$ and 3 $(100 \%)$ of 3 participants having the mutant homozygous genotype $\left({ }^{*} 2 /{ }^{*} 2\right)$, who were intolerant to alcohol. These results were consistent with the genotypes.
Table 3: Behavior Characterisitics of Participants to Alcohol Bevarages

\begin{tabular}{|c|c|c|c|}
\hline Subjects $(\mathbf{n}=\mathbf{1 1 3})$ & Number & \multicolumn{2}{|c|}{ Number of ALDH2 genotype } \\
\hline \hline Non-drinker & 2 & $2^{*} 2^{*}=2$ & \\
\hline Chance drinker* $^{*}$ & 88 & $1^{*} 1^{*}=55$ & $1^{*} 2^{*}=33$ \\
\hline Past drinker ${ }^{* *}$ & 23 & $1^{*} 1^{*}=15$ & $1^{\star} 2^{*}=8$ \\
\hline
\end{tabular}

${ }^{*}$ Non-drinker: 0 times a week.

${ }^{* *}$ Chance drinker: less than 4 times a week.

${ }^{* * *}$ Past drinker: non-drinker but has drunk in the past.

Table 4: The Subjects' Ethanol Patch Test Results According to Genotype

\begin{tabular}{|c|c|c|c|}
\hline \multirow{2}{*}{ Skin reaction } & \multicolumn{3}{|c|}{ Genotype } \\
\cline { 2 - 4 } & ${ }^{*} \mathbf{1} / \mathbf{1}$ & ${ }^{*} \mathbf{1} /{ }^{*} \mathbf{2}$ & ${ }^{*} \mathbf{2} /{ }^{*} \mathbf{2}$ \\
\hline \hline Negative & 88 & 3 & 0 \\
\hline Positive & 7 & 43 & 3 \\
\hline Total & 95 & 46 & 3 \\
\hline
\end{tabular}

$x^{2}=104.065, p<0.00001$.

Negative: not changed.

Positive: changed to red.

\section{DISCUSSION}

Subtilisin-like proteases are generally bacterial in origin and secreted extracellularly for the purpose of scavenging nutrients [18-21]. They are highly sensitive towards phenyl methyl sulfonyl fluoride and diisopropylfluorophosphate, but not to chelating agents such as EDTA. Thus, we employed MIB029 protease to extract DNA from nail clippings containing strong DNases. pNCMO2 used in the present study is a shuttle vector for $B$. subtilis and E. coli . Therefore, we constructed the plasmid in $E$. coli and then introduced the plasmid into $B$. subtilis for protein expression. Using standard molecular cloning techniques, keratiolytic activity was successively elevated by 5 -fold compared with the mother strain MIB029.

Fingernails, which are composed of the strong protein keratin, are produced in living skin cells in the fingers. The free edge of the nail extends past the finger and beyond the nail plate. There are no nerve endings in the nail. The growing part of the nail remains under the skin at the proximal end. Thus, we selected nail clippings as a tool for extracting genetic material. No subjects refused to provide nail clippings as DNA specimens. Person with ALDH2 ${ }^{*} 1$ homozygote have a higher acceptable alcohol consumption level, they are more predisposed to alcoholism or many other alcoholrelated diseases. The ALDH2*2 gene, which almost 
half of the Oriental population carry, appears to provide a significant advantage in that it leads to the prevention of the development of such diseases due to excessive alcohol consumption.

Our results demonstrate that cloned protease works more actively at $\mathrm{pH} 11.0$ for extracting DNA from nail clippings than the protease of either Cucumis melo or proteinase $\mathrm{K}$. The purity of DNA materials obtained using MIB029 protease was the same as that obtained for Cucumis melo protease [11]. Moreover, MIB029 protease has several advantages over than the fruit enzyme: for one, there is no seasonal limitation for obtaining the fruit; in addition, the samples show higher consistency in activity levels.

When our genetic diagnostic method using nail clippings was compared with the alcohol patch test and TAST, we encountered no disadvantages such as skin irritation or allergic symptoms among our subjects, unlike in the alcohol patch test. In addition, no variability was observed in the assessment results depending on the subjects' physical conditions at examination, as seen in the adolescent female subjects. The TAST contains many questions that are assumed to be answered by individuals with a history of alcohol consumption and thus are often inappropriate for minors in terms of its content [3,4]. Although behavioral characteristics related to alcohol consumption were investigated only in the participants with a history of alcohol consumption, no results consistent with genotypes were obtained (Table 4), probably owing to the influence of the participants' daily lifestyles rather than their constitutional predisposition to drinking habits.

Our diagnostic method, which uses easily collected fingernail samples as a source of DNA and enables assessment on the basis of resultant genotypes, may be considered as one of the most appropriate tools for screening alcohol sensitivity in minors, as it does not rely on the examiner's subjective assessment and is less affected by the subject's mental status.

In summary, the public should be educated as early as possible during the junior/high school years [3, 2225]. The ratio of three genotypes for ALDH2 shown in Figure 5 indicates the typical ratio to Mongoloids concerning to alcohol tolerance $[1,4,5]$. Racial differences in alcohol metabolism are known to exist, which appear to be substantially influenced by genetic factors. The proportion of people with low alcoholmetabolizing activity is greater in Asians than in
Caucasians [1]. We are currently examining the ALDH2 genotype both in university students in North America and in residents of Mwanza, Tanzania.

\section{ACKNOWLEDGEMENTS}

This work was supported by JSPS KAKENHI Grant Number 16500144. We thank to Ms. Megumu Yano, University of Tsukuba, for her technical assistances through the study.

\section{REFERENCES}

[1] Yanagisawa $\mathrm{Y}$, Munkhtulga L, Nakayama K, et al. Diversity in genes responsible for lifestyle-related diseases in AsiaPacific region. Asia Pac J Public Health 2008; 20(Suppl): 257-61.

[2] Enoch MA. The influence of gene-environment interactions on the development of alcoholism and drug dependence. Curr Psychiatry Rep 2012; 14(2): 150-8. http://dx.doi.org/10.1007/s11920-011-0252-9

[3] Tarter RE, Kirisci L, Clark DB. Alcohol use disorder among adolescents: impact of paternal alcoholism on drinking behavior, drinking motivation, and consequences. Alcohol Clin Exp Res 1997; 21(1): 171-8. DOI:10.1111/j.15300277.1997.tb03745.x

[4] Hashimoto Y, Nakayama T, Futamura A, et al. Relationship between genetic polymorphisms of alcohol-metabolizing enzymes and changes in risk factors for coronary heart disease associated with alcohol consumption. Clin Chem 2002; 48(7): 1043-8.

[5] Harada S, Agarwal DP, Goedde HW. Aldehyde dehydrogenase deficiency as cause of facial flushing reaction to alcohol in Japanese. Lancet 1981; 2(8253): 982. http://dx.doi.org/10.1016/S0140-6736(81)91172-7

[6] Yoshida A. Genetic polymorphisms of alcohol metabolizing enzymes related to alcohol sensitivity and alcoholic diseases. Alcohol Alcoholism 1994; 29(6): 693-6.

[7] Higuchi S, Matsushita S, Masaki T, et al. Influence of genetic variations of ethanol-metabolizing enzymes on phenotypes of alcohol-related disorders. Ann NY Acad Sci 2004; 1025: 47280.

http://dx.doi.org/10.1196/annals. 1316.058

[8] Higuchi S. Significance of ethanol patch test. Nippon Rinsho (Japanese J Clin Med) 1997; 55(Suppl): 582-587.

[9] Mayer J, Filstead WJ. The Aldolescent Alcohol Involvement Scale: An instrument for measuring aldolescents' use and misuse of alcohol. J Stud Alcohol 1979; 40: 291-300.

[10] Yamauchi M, Kimura T, Takeda K, et al. Ethanol patch test: a simple method for identifying the effectiveness of cyanamide in alcoholics. Alcohol Clin Exp Res. 2000; 24(4 Suppl): 39S$42 \mathrm{~S}$.

[11] Yoshida-Yamamoto S, Nishimura S, Okuno T, Rakuman M, Takii Y. Efficient DNA extraction from nail clipping using the protease solution from Cucumis melo. Mol Biotechnol 2010; 46(1): 41-8. http://dx.doi.org/10.1007/s12033-010-9273-6

[12] Takii Y, Kuriyama S, Suzuki Y. Alkaline serine protease produced from citric acid by Bacillus alcalophilus subsp. halodurans KP1239. Appl Microbiol Biotech 1990; 34(1): 5762. http://dx.doi.org/10.1007/BF00170924

[13] Saito $\mathrm{H}$, Miura T. Preparation of transforming deoxyribonucleic acid by phenol treatment. Biochim Biophys Acta 1963; 72: 619-29.

http://dx.doi.org/10.1016/0926-6550(63)90386-4 
[14] Takami H, Kobayashi $\mathrm{T}$, Kobayashi $\mathrm{M}$, et al. Molecular cloning, nucleotide sequence, and expression of the structural gene for alkaline serine protease from alkaliphilic Bacillus sp 221. Biosci Biotechnol Biochem 1992; 56(9): 1455-60. http://dx.doi.org/10.1271/bbb.56.1455

[15] Smith EL, Delange RJ, Evans WH, Landon M, Markland FS. Subtilisin Carlsberg V: the complete sequence; comparison with subtilisin BPN';evolutionary relationships. J Biol Chem 1968; 243(9): 2184-91.

[16] Wells JA, Ferrari E, Henner DJ, Estell DA, Chen EY. Cloning, sequencing, and secretion of Bacillus amyloliquefaciens subtilisin in Bacillus subtilis. Nucl Acids Res 1983; 11(22): 7911-25.

http://dx.doi.org/10.1093/nar/11.22.7911

[17] Kobayashi T, Hakamada Y, Adachi S, et al. Purification and properties of an alkaline protease from alkalophilic Bacillus sp. KSM-K16. Appl Microbiol Biotechnol 1995; 43(3): 473-81. http://dx.doi.org/10.1007/BF00218452

[18] Gupta R, Beg QK, Lorenz P. Bacterial alkaline proteases: molecular approaches and industrial applications. Appl Microbiol Biottechnol 2002; 59(1): 15-32. http://dx.doi.org/10.1007/s00253-002-0975-y

[19] Gupta R, Ramnami P. Microbial keratinases and their prospective applications: an overview. Appl Microbiol Biotechnol 2006; 70(1): 21-23.

http://dx.doi.org/10.1007/s00253-005-0239-8
[20] Mitsuiki S, Sakai M, Moriyama Y, Goto M, Furukawa K. Purification and some properties of a keratinolytic enzyme from an alkaliphilic Nocardiopsis sp. TOA-1. Biosci Biotechnol Biochem 2002; 66(1): 164-7.

http://dx.doi.org/10.1271/bbb.66.164

[21] Bach E, Daroit DJ, Corrêa AP, Brandelli A. Production and properties of keratinolytic proteases from three novel Gramnegative feather-degrading bacteria isolated from Brazilian soils. Biodegradation 2011; 22(6): 1191-201. http://dx.doi.org/10.1007/s10532-011-9474-0

[22] Allen JP, Litten RZ, Fertig JB, Babor T. A review of research on the Alcohol Use Disorders Identification Test (AUDIT). Alcohol Clin Exp Res 1997; 21(4): 613-9. http://dx.doi.org/10.1111/j.1530-0277.1997.tb03811.x

[23] Holman CDJ, English DR, Milne E, Winter MG. Meta-analysis of alcohol and all-cause mortality: a validation of NHMRC recommendations. Med J Aust 1996; 164: 141-5.

[24] Zarkin GA, Bra JW, Babor TF, Higgins-Biddle JC. Alcohol drinking patterns and health care utilization in a managed care organization. Health Serv Res 2004; 39(3): 553-70. http://dx.doi.org/10.1111/j.1475-6773.2004.00244.x

[25] Goedde HW, Agarwal DP, Fritze G, et al. Distribution of ALDH2 and ALDH2 genotypes in different populations. Hum Genet 1992; 88(3): 677-81. http://dx.doi.org/10.1007/BF00197271

Received on 22-07-2013

(c) 2013 Nagayoshi et al.; Licensee Lifescience Global.

This is an open access article licensed under the terms of the Creative Commons Attribution Non-Commercial License (http://creativecommons.org/licenses/by-nc/3.0/) which permits unrestricted, non-commercial use, distribution and reproduction in any medium, provided the work is properly cited. 